\title{
Retraction: Characterization of follicle populations in mare ovaries: from preantral to preovulatory follicles
}

\author{
Editorial Board of Journal of Morphological Sciences
}

\section{Retracted article:}

LEONEL, ECR., BENTO-SILVA, V., COSTA E SILVA, EV. and ZÚCCARI, CESN. Characterization of follicle populations in mare ovaries: from preantral to preovulatory follicles. Journal of Morphological Sciences, 2015, vol. 32, n. 3, p. $176-181$. http://dx.doi.org/10.4322/jms.084715

\section{Retraction date:}

September 16th 2016

\section{Retraction requested by:}

All authors.

\section{Retraction type:}

Honest error that generated a duplicate publication.

\section{Comment:}

Due to honest error the typesetting service provider of J. Morphol. Sci failed to remove an article from it's production workflow despite having acknowledged the Editors and Author's request to do so. As a result the article was published by J.
Morphol. Sci in redundance after been already published by ENCICLOPÉDIA BIOSFERA. Thus, Authors and Editors would like to jointly withdraw the article aforementioned and recommend that all citations be made to the article published by ENCICLOPÉDIA BIOSFERA (LEONEL, BENTO-SILVA, COSTA E SILVA et al., 2015).

\section{References}

LEONEL, ECR., BENTO-SILVA, V., COSTA E SILVA, EV. and ZÚCCARI, CESN. Follicle populations in mare ovaries: from preantral to preovulatory follicles. Enciclopédia Biosfera, 2015, vol. 11, n. 22, p. 1321-1333. http://dx.doi.org/10.18677/Enciclopedia_ Biosfera_2015_162. 


\title{
Characterization of follicle populations in mare ovaries: from preantral to preovulatory follicles
}

\author{
LEONEL, E. C. R. ${ }^{1 *}$, BENTO-SILVA, V. ${ }^{2}$, COSTA E SILVA, E. V. ${ }^{3}$ and \\ ZÚCCARI, C. E. S. N. ${ }^{2}$
}

'Department of Biology, Institute of Biosciences, Humanities and Exact Sciences, Universidade Estadual Paulista
"Júlio de Mesquita Filho" - UNESP, CEP 15054-000, São José do Rio Preto, SP, Brazil
2Reproduction Biotechnology Laboratory, School of Veterinary Medicine and Animal Science,
Universidade Federal do Mato Grosso do Sul - UFMS, Avenida Senador Felinto Müller, 2443,
CEP 79070-900, Campo Grande, MS, Brazil
${ }^{3}$ Animal Reproduction Laboratory, School of Veterinary Medicine and Animal Science, Universidade Federal do Mato Grosso do Sul - UFMS, Avenida Senador Felinto Müller, 2443,

CEP 79070-900, Campo Grande, MS, Brazil

*E-mail: ellenleonel@yahoo.com.br

\begin{abstract}
Introduction: The equine ovary is peculiar in that, unlike other mammalian ovaries, its germinal surface, where follicles and oocytes are found, is located at the organ's central portion, while its conjunctive tissue and vessels are found in the external layer. The purpose of this study was to describe morphological and quantitative aspects of preantral and antral follicles in the equine ovary. Materials and Methods: Of the 189 mare ovaries evaluated, six were collected from necropsied mares and sliced lengthwise parallel to the oyulation fossa. The slices were fixed and processed for histological evaluation under light microscopy. Preantral follicles were classified according to developmental stage and as morphologically normal or degenerated. For the remaining 183 ovaries, obtained from an abattoir, antral follicles were measured, punctured and oocytes evaluated. Oocyte recovery rates were calculated for each follicle size category. A total of 490 preantral follicles were examined. Results: Primary follicles were in greater number than primordial follicles. No secondary follicles were found. A total of 518 antral follicles were punctured and evaluated. Total oocyte recovery rate was 47.6. Preantral follicles were scarce in the equine ovary. Conclusion: Oocyte recovery rate was higher for smaller-diameter antral follicles.
\end{abstract}

Keywords: antral follicle, morphology, mare, ovary, preantral follicle.

\section{Introduction}

Akin to some species, equine ovaries are both endocrine-secreting, among other hormones, $17 \beta$-estradiol-and exocrine-generating germinative female cells: the oocytes (BRINSKO, BLANCHARD and VARNER, 2011). They are located ventrally to the 4th or 5 th lumbar vertebra and most of their surface is covered by peritoneum, except at the hilus, the small portion where vessels and nerves are inserted (HARE and BETTERIDGE, 1978).

The equine vary is peculiar in that, unlike other mammalian ovaries, its germinal surface, where follicles and oocytes are found, is located at the organ's central portion, while its conjunctive tissue and vessels are found in the external layer. Consequenty, ovulation takes place only in the ovulation fossa, which begins to develop in early gestation, when the ovarian cortical layer, where preovulatory follicles (POFs) will be present, starts to contract and invaginate (WALT, STABENFELDT, HUGHES et al., 1979).

Of the several different cell types found in the ovarian structure, conjunctive tissue cells, oocytes, and both granulosa and theca cells are the most important. Mammalian ovaries have a reserve pool of germ cells: the oocytes included in preantral follicles (PAFs). These structures are to ensure reproduction capacity throughout the reproductive life of females, conserving oocytes until ovulation time (SILVA-SANTOS, SANTOS, SILOTO et al., 2011). Because PAFs are available in great numbers, their use is advantageous for the preservation of genomic material and development of new individuals from these oocytes.

POFs have been extensively used in breeding protocols. Employing POFs in biotechniques such as artificial insemination (LOOMIS, 1986), embryo transfer (PESSOA, CANNIZZA, REGHINI et al., 2011), intracytoplasmic injection of spermatozoa (COCHRAN, MEINTJES, REGGIO et al., 1998), and use of sexed semen (SAMPER, MORRIS, PEÑA et al., 2012) has led to considerable advancements in the areas of reproductive physiology, gametogenesis, and embryogenesis (AURICH, 2012).

Importantly, these biotechniques have not only had a marked impact on the quality of genetic resources from livestock species, but have also led to the creation of germplasm banks, which allow genetic material from endangered species to be preserved (LEON-QUINTO, SIMON, CADENAS et al., 2009).

With regard to POFs, oocyte recovery rate and oocyte quality can be affected by several factors, including the recovery technique adopted, follicle size, and time elapsed between puncture and beginning of culture. Oocytes can be obtained from slaughtered animals (SUTTON-MCDOWALL, YELLAND, MACMILLAN et al., 2014), by ultrasound-guided ovarian puncture in vivo, (IACONO, MERLO, RIZZATO et al., 2014) 
or by laparoscopy-assisted methods (REICHENBACH, WIEBKE, MÖDL et al., 1994).

However, relevant information on early folliculogenesis, and likewise about mare follicle population, is scarce, although PAFs have been quantified and characterized in other mammalian species. Follicle population per ovary is highly variable across species, having been estimated at 35000 in caprines (LUCCI, AMORIM, RODRIGUES et al., 1999) and 160000 in ovines (AMORIM, LUCCI, RODRIGUES et al., 2000). PAFs can be frozen and/or cultured in vivo or in vitro and developed until a suitable stage when in vitro fertilization (IVF) can be performed.

In equines, oocyte recovery followed by IVF is crucial for commercial embryo transfer programs. Although frozen oocytes can be kept in banks for future fertilization, the retrieval and viability of maintaining these cells pose a considerable challenge for IVF and embryo transfer programs (THARASANIT, COLLEONI, LAZZARI et al., 2006).

Although the morphology and viability of normal cumulus-oocyte complexes have been investigated (CURCIO, GASTAL, PEREIRA et al., 2014; FOSS, ORTIS and HINRICHS, 2013), scant data are available on the effect of follicular diameter on oocyte recovery rates. Abattoirs are a promising option for obtaining equine oocytes in great numbers, since gonads would otherwise be discarded (DELL'AQUILA, $\mathrm{CHO}$, MINOIA et al., 1997). Another advantage is that mares sent to abattoirs have not been subjected to superovulation procedures or other reproductive treatments, thereby allowing ovaries to be evaluated under normal physiological conditions. Also, characterization and quantification of equine follicles can help improve methods of isolating PAFs for in vitro culture, as well as POF puncture in IVF.

The purposes of this study were to describe morphological and quantitative aspects of the preantral follicle population in equine ovaries and to evaluate the effect of follicular diameter on the recovery rates of oocytes harvested from equin ovaries obtained from an abattoir.

\section{Materials and Methods}

Equine ovaries $(n=189)$ were collected from 183 mares slaughtered in an abattoir and rom six mares subjected to euthanasia in a veterinary hospital due to trauma or colic syndrome. Mare ages (range 2-23 years) were determined based on dental arcade features. One animal was a fetus with a gestational age of 7 months. All adult mares died during the ovulatory season All animals were crossbred.

\subsection{Experiment 1}

The ovaries obtained from necropsied euthanized animals (October, $20^{\circ} 26^{\prime} 34^{\prime \prime} \mathrm{S}, 54^{\circ} 38^{\prime} 47^{\prime \prime} \mathrm{W}$ ) were collected immediately after opening the abdominal cavity and then sent to the laboratory for determinations of weight and measurements. For evaluation of PAFs, the ovaries were sliced lengthwise into $3 \mathrm{~mm}$-thick fragments, parallel to the ovulation fossa. During manipulation, the fragments were kept in phosphate buffer saline (PBS) at $38{ }^{\circ} \mathrm{C}$ and fixed in Carnoy's fluid $(60 \%$ ethanol, $30 \%$ chloroform, and $10 \%$ glacial acetic acid) for $12 \mathrm{~h}$. Fragments were then processed for histology, as follows: serial dehydration in ethanol $(70 \%, 80 \%, 90 \%$, and $100 \%)$; clarification in xylene; paraffin embedding; and transection in a microtome ( $5 \mu \mathrm{m}$ thickness). The slices were cut every $50 \mu \mathrm{m}$ to avoid counting the same follicle twice and then subjected to periodic acid-Schiff (PAS) reaction to allow identification of the basement membrane. For evaluation of PAF morphology, only follicles having the oocyte nucleus in the slice being observed were classified as primordial (one flattened granulosa cell layer) or primary (one cuboidal granulosa cells layer).

The follicles were also classified as morphologically normal or degenerated, based on granulosa cell features (morphology and density), nucleus characteristics, basement membrane integrity, and presence of pyknotic bodies (Table 1).

Descriptive statistics were employed for data treatment.

\subsection{Experiment 2}

The ovaries obtained from the abattoir (January, $23^{\circ} 25^{\prime \prime} 38^{\prime \prime} \mathrm{S}$, $\left.51^{\circ} 56^{\prime} 15^{\prime \prime} \mathrm{W}\right)$ were collected from the inspection table, placed in containers with $0.9 \%$ physiologic saline plus penicillin $(100 \mathrm{UI} / \mathrm{mL})$ and streptomycin $(50 \mathrm{Hg} / \mathrm{mL})$, and sent to the laboratory, where the antral follicies detected on the ovarian surface were counted, measured, and categorized according to diameter as Class A $(\leq 15 \mathrm{~mm})$, Class B $(20-30 \mathrm{~mm})$, or Class $\mathrm{C}(\geq 35 \mathrm{~mm})$. Oocytes were harvested by follicle puncture performed with an $18 \mathrm{G}$ needle attached to a syringe. The follicular thuid was added to phosphate buffer saline (PBS), 10\% fetal calf serum (FCS), penicillin (100 UI/mL), and streptomycin $(50 \mu \mathrm{g} / \mathrm{mL})$. The resulting mixture was decanted in a test tube, the supernatant discarded, and the cells transferred to a Petri dish for oocyte evaluation under a stereoscopic microscope.

The data were subjected to ANOVA. Tukey's test was employed to compare means. Differences were considered significant for values of $p<0.05$.

\section{Results}

Of the 189 ovaries investigated, $168(88.88 \%)$ had several antral follicles on their surface. Of these 168, 70 (41.66\%) showed corpora lutea. Mean ovarian length, width, and

Table 1. Morphological classification of equine preantral follicles according to histological features (normal or degenerated) after periodic acid-Schiff (PAS) reaction.

\begin{tabular}{|c|c|}
\hline Classification & Morphological features \\
\hline \multirow[b]{2}{*}{ Normal (N) } & Intact oocyte \\
\hline & $\begin{array}{l}\text { Organized granulosa cells and } \\
\text { non-degraded nucleus }\end{array}$ \\
\hline \multicolumn{2}{|c|}{ Type 1 degeneration } \\
\hline \multirow{3}{*}{ TlA } & Contracted oocyte \\
\hline & Pyknotic nucleus \\
\hline & Non-degraded basement membrane \\
\hline \multirow{3}{*}{ T1B } & Contracted oocyte \\
\hline & Pyknotic nucleus \\
\hline & Degraded basement membrane \\
\hline \multicolumn{2}{|c|}{ Type 2 degeneration } \\
\hline \multirow{3}{*}{$\mathrm{T} 2 \mathrm{~A}$} & Pyknotic oocyte \\
\hline & Granulosa cell disorganization \\
\hline & Non-degraded basement membrane \\
\hline \multirow{3}{*}{$\mathrm{T} 2 \mathrm{~B}$} & Pyknotic oocyte \\
\hline & Granulosa cell disorganization \\
\hline & Degraded basement membrane \\
\hline
\end{tabular}


thickness $(\mathrm{mm})$ were $55.74 \pm 12.95,41.97 \pm 11.02$, and $35.17 \pm 13.39$, respectively. Mean weight was $37.03 \pm 31.26 \mathrm{~g}$.

Of the 490 PAFs counted in experiment 1, 199 were primordial (40.6\%; Table 2) and 291 primary (59.4\%; Table 3 ) (Figure 1) - i.e., their numbers were very small in both cases, a large variation in the numbers of follicles of each class was evident across animals, and even an absence of primordial follicles occurred in the oldest mare ( 23 years). This caused most standard deviation values to be higher than the means (Tables 2 and 3).

Among the 168 ovaries in the second experiment, 518 antral follicles were punctured. Follicle categorization was distributed as follows: Class A, 61.9\% (321): Class B, 26.8\% (139); Class C, $11.1 \%$ (58). Stratified by category, recovery rates were as follows: Class A, 53.5\%; Class B, 35.9\%; Class C, $43.1 \%$. The overall oocyte recovery rate was $47.6 \%$. Mean number of follicles per ovary was 3.0. Mean numbers in each class were as follows: Class A, 1.9 (321/518); Class B, 0.8 (139/518); Class C, $0.3(58 / 518)$. Mean number of oocytes obtained by puncture was 1.47 per ovary. Relationships between follicle diameters and oocyte recovery rates are shown in Table 4.

Ovarian sizes and corpus luteum percentages (41.66\%) were consistent with the season of ovary collection and the corresponding reproductive cycle stage in mares.
Identifying PAFs in situ in equine ovaries is a more complex task than in other mammals. Lucci, Kacinskis, Lopes et al. (2004), employing cryopreservation techniques, identified 4901 follicles in bovine ovaries (LUCCI, KACINSKIS, LOPES et al., 2004). In mares, however, the germinative epithelium is limited to the ovulation fossa, yet PAFs can be found in the entire ovarian stroma in groups of 2 to 7 follicles, although they more often occur singly, as observed in the present experiment (SZLACHTA and TISCHNER, 1998). These factors contribute to the difficulties experienced locating follicles in the equine ovary, given the size of this gonad.

In mares, Driancourt, Paris, Roux et al. (1982) found a higher number of PAFs (35950 of them primordial and 100 primary or secondary) per ovary (DRIANCOUR, PARIS, ROUX et al., 1982). By contrast, mares in the present study had a higher percentage of primary than primordial follicles. Low percentages of primordial follicles have also been observed in other species. Examining elephant ovaries, Stansfield, Picton and Nöthling (2011) found that the ovarian follicle reserve harbored $75 \%$ primary follicles, but only $2 \%$ primordial follicles (STANSFIELD, PICTON and NÖTHLING, 2011).

In older mammals, low percentages of follicles may be due to atresia or apoptosis (GNTHER, 1992), or to oocyte consumption along the lifespan. Follicle populations are not

Table 2. Distribution of primordial follicles per equine ovary, by morphological class

\begin{tabular}{|c|c|c|c|c|c|c|c|}
\hline \multirow{2}{*}{ Animal } & \multirow{2}{*}{ Age (years) } & \multicolumn{5}{|c|}{ Primordial follicles } & \multirow{2}{*}{ Total } \\
\hline & & Normal & TIA & T1B & T2A & T2B & \\
\hline 1 & 23 & 0 & 0 & 0 & 0 & 0 & 0 \\
\hline 2 & 18 & 0 & 0 & & 0 & 8 & 9 \\
\hline 3 & 14 & 1 & 0 & 0 & 0 & 13 & 14 \\
\hline 4 & 8 & 0 & & 0 & 5 & 3 & 14 \\
\hline 5 & 2 & 5 & 11 & 0 & 13 & 47 & 76 \\
\hline 6 & 0.58 & 2 & & 0 & 45 & 28 & 86 \\
\hline \multicolumn{2}{|c|}{ Total } & 8 & 28 & 1 & 63 & 99 & 199 \\
\hline \multirow{2}{*}{\multicolumn{2}{|c|}{$\begin{array}{c}\text { Mean } \pm \\
\text { SD }\end{array}$}} & 1.33 & 4.666 & 0.166 & 16.5 & 10.5 & 33.166 \\
\hline & & 1.966 & 5.428 & 0.408 & 17.896 & 17.649 & 37.536 \\
\hline
\end{tabular}

Table 3. Distribution of primary follicles per equine ovary, by morphological class.

\begin{tabular}{|c|c|c|c|c|c|c|}
\hline \multirow{2}{*}{ Animal } & \multicolumn{5}{|c|}{ Primary follicles } & \multirow{2}{*}{ Total } \\
\hline & Normal & T1A & T1B & T2A & T2B & \\
\hline 1 & 0 & 0 & 0 & 0 & 5 & 5 \\
\hline 2 & 0 & 0 & 0 & 2 & 2 & 2 \\
\hline 3 & 0 & 1 & 0 & 2 & 6 & 7 \\
\hline & 0 & 1 & 0 & 4 & 6 & 12 \\
\hline & 10 & 18 & 5 & 8 & 91 & 137 \\
\hline & 4 & 13 & 0 & 10 & 66 & 128 \\
\hline & 14 & 33 & 5 & 176 & 26 & 291 \\
\hline & 2.333 & 5.5 & 0.833 & 4.333 & 29.333 & 48.5 \\
\hline & 4.082 & 7.918 & 2.041 & 3.881 & 38.923 & 65.209 \\
\hline
\end{tabular}

Table 4. Rates of oocyte recovery from equine ovaries, by follicular diameter.

\begin{tabular}{|c|c|c|c|}
\hline \multirow{2}{*}{ Variables } & \multicolumn{3}{|c|}{ Follicular diameter } \\
\hline & $\mathrm{A}(\leq 15 \mathrm{~mm})$ & $\mathrm{B}(20-30 \mathrm{~mm})$ & $\mathrm{C}(\geq 35 \mathrm{~mm})$ \\
\hline Punctured follicles (\%) & $61.9^{a}$ & $26.8^{\mathrm{b}}$ & $11.1^{\mathrm{c}}$ \\
\hline Oocyte recovery (\%) & $53.5^{\mathrm{a}}$ & $35.9^{\mathrm{b}}$ & $43.1^{\mathrm{a}, \mathrm{b}}$ \\
\hline
\end{tabular}

${ }^{\mathrm{a}-\mathrm{c}}$ Different letters in same row indicate significant differences $(p<0.05)$. 


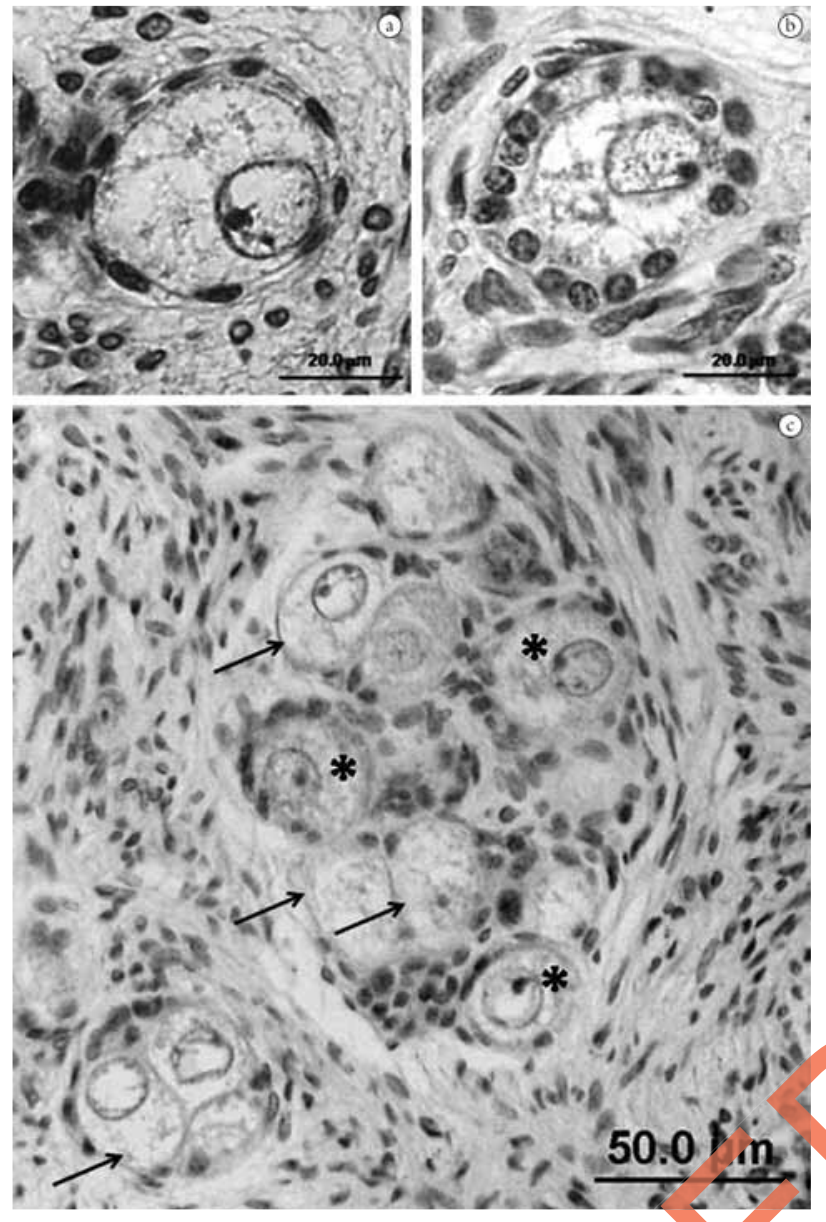

Figure 1. Normal equine preantral follicles: primordial follicie (a); primary follicle (b); pool of follicles (c) with primordial (arrows and primary follicles (asterisks).

renewed in most mammalian species, including mares-although rare instances have been described in humans (BUKOVSKY, CAUDLE, SVETLIKOVA et al., 2004).

In the present study, secondary follicles were not observed among growing follicles, at any stage. Secondary follicles are typically found in small numbers, given their short lifespan (MÜLLER, ELLENBERGER and SCHOON, 2009). Evaluating PAF populations in situ in mare ovaries, Haag, Magalhães Padilha, Fonseca et al. (2013) found only primordial and primary follicles, similarly to the present study.

In the present investigation, the rate of aspiration was higher for Class A antral follicles, followed by Classes B and C-results corroborating those of Hinrichs (1991), who found the proportion of viable follicles to rise with increasing follicle . Zúccari, Bender, Silva et al. (2013) observed mean follicle populations, evaluated by rectal palpation, of $2.84,1.15$, and 1.15 for Classes A, B, and C, respectively (ZÚCCARI, BENDER, SILVA et al., 2013) (employing the same criteria for class definition as the present study).

Oocyte recovery rate was 47.6 in the present investigation, lower than the $54 \%$ obtained by Jacobson, Choi, Hayden et al. (2010), who employed hormonal manipulation to cycle mares (JACOBSON, CHOI, HAYDEN et al., 2010).

In mares, the oocyte-cumulus complex is attached to the follicle wall by a wide base (GINTHER, 1992), contrasting with other species, in which cumulus cells exhibit a pedunculated structure - a histological feature likely to promote stronger oocyte adhesion, resulting in lower recovery rates, especially when collection involves aspiration.

Follicle external diameter has an effect on oocyte quality and oocyte developmental competence after maturation, fertilization, and in vitro culture (GOUDET, BEZARD, DUCHAMP et al., 1997). Experiments conducted on different species have revealed that large follicle size may be related to increased percentages of fertile oocytes during IVF in bovines (PAVLOK, LUCAS-HAHN and NIEMANN, 1992), swine (LUCAS, MARTÍNEZ, ROCA et al., 2003), and humans (TEISSIER, CHABLE, PAULHAC et al., 2000).

In the present investigation, Class A ovaries contained larger follicle populations available for oocyte aspiration. Recovery rates were higher for Class A than for Class B follicles. For IVF protocols, two issues have yet to be resolved: ef ficient methods for both oocyte recovery and sperm preparation for in vitro fertilization.

\section{Conclusion}

In mares, germ cells in the ovarian stroma exhibit a peculiar organization that differs from most mammalian species. Follicles can be found in groups or isolated. PAFs occur in small numbers. Printary follicles occur at higher percentages. Secondary follicles were absent. Antral follicles measuring $15 \mathrm{~mm}$ or less constituted the largest population available for oocyte aspiration, with higher recovery rates.

Acknowledgements: This investigation was supported by the Brazilian Council for Scientific and Technological Development (CNPq). No conflicts of interest exist that may be detrimental to the impartiality of the research reported.

\section{References}

AMORIM, CA., LUCCI, CM., RODRIGUES, APR., CARVALHO, FCA., FIGUEIREDO, JR., RONDINA, D., CECCHI, R., GIORGETTI, A., MARTINI, A. and GONÇALVES, PB. Quantitative and qualitative analysis of the effectiveness of a mechanical method for the isolation of preantral follicles from ovine ovaries. Theriogenology, 2000, vol. 53, n. 6, p. 1251-1262. http://dx.doi.org/10.1016/ S0093-691X(00)00269-7. PMid:10832750.

AURICH, JE. Artificial insemination in horses: more than a century of practice and research. Journal of Equine Veterinary Science, 2012, vol. 32 , n. 8, p. 458-463. http://dx.doi.org/10.1016/j.jevs.2012.06.011.

BRINSKO, SP., BLANCHARD, TL. and VARNER, DD. Manual of equine reproduction. St Louis: Elsevier, 2011. 363p.

BUKOVSKY, A., CAUDLE, MR., SVETLIKOVA, M. and UPADHYAYA, NB. Origin of germ cells and formation of new primary follicles in adult human ovaries. Reproductive Biology and Endocrinology, 2004, vol. 2, n. 1, p. 1-30. http://dx.doi.org/10.1186/1477-7827-2-1. PMid:15115550.

COCHRAN, R., MEINTJES, M., REGGIO, B., HYLAN, D., CARTER, J., PINTO, C., PACCAMONTI, D. and GODKE, RA. Live foals produced from sperm-injected oocytes derived from pregnant mares. Journal of Equine Veterinary Science, 1998, vol. 18, n. 11, p. 736-740. http://dx.doi.org/10.1016/S0737-0806(98)80504-2.

CURCIO, BR., GASTAL, MO., PEREIRA, GR., CORCINI, CD., LANDIM-ALVARENGA, FC., BARROS., NOGUEIRA, CEW., DESCHAMPS, JC. and GASTAL, EL. Ultrastructural morphology and nuclear maturation rates of immature equine oocytes vitrified with different solutions and exposure times. Journal of Equine 
Veterinary Science, 2014, vol. 34, n. 5, p. 632-640. http://dx.doi. org/10.1016/j.jevs.2013.12.002.

DELL'AQUILA, ME., CHO, YS., MINOIA, P., TRAINA, V., FUSCO, S., LACALANDRA, GM. and MARITATO, F. Intracytoplasmic sperm injection (ICSI) versus conventional IVF on abattoir-derived and in vitro-matured equine oocytes. Theriogenology, 1997, vol. 47, n. 6, p. 1139-1156. http://dx.doi.org/10.1016/S0093-691X(97)00095-2. PMid:16728064.

DRIANCOURT, MA., PARIS, A., ROUX, C., MARIANA, JC. and PALMER, E. Ovarian follicular populations in pony and saddletype mares. Reproduction, Nutrition, Development, 1982, vol. 22, n. 6, p. 1035-1047. http://dx.doi.org/10.1051/rnd:19820714 PMid:7163613.

FOSS, R., ORTIS, H. and HINRICHS, K. Effect of potential oocyte transport protocols on blastocyst rates after intracytoplasmic sperm injection in the horse. Equine Veterinary Journal, 2013, vol. 45, n. 45, p. 39-43. http://dx.doi.org/10.1111/evj.12159. PMid:24304402.

GINTHER, OJ. Reproductive anatomy. Wisconsin: Equiservices, 1992. 549 p.

GOUDET, G., BEZARD, J., DUCHAMP, G., GERARD, N. and PALMER, E. Equine oocyte competence for nuclear and cytoplasmic in vitro maturation: effect of follicle size and hormonal environment. Biology of Reproduction, 1997, vol. 57, n. 2, p. 232-245. http:// dx.doi.org/10.1095/biolreprod57.2.232. PMid:9241036.

HAAG, KT., MAGALHÃES-PADILHA, DM., FONSECA, GR., WISCHRAL, A., GASTAL, MO., KING, SS., JONES, KL., FIGUEIREDO, JR. and GASTAL, EL. Equine preantral follicles obtained via the Biopsy Pick-up method: Histological evaluation and validation of a mechanical isolation technique. Theriogenology, 2013, vol. 79, n. 5, p. 735-743. http://dx.doi.org/10.1016/j. theriogenology.2012.10.023. PMid:23352704.

HARE, WCD. and BETTERIDGE, KJ. Relationship of embryo sexing to other methods of prenatal sex determination in farm animals: a review. Theriogenology, 1978, vol. 9, n. 1, p. 27-43. http://dx.do org/10.1016/0093-691X(78)90050-X.

HINRICHS, K. The relationship of follicle atresia to follicle size, oocyte recovery rate on aspiration, and oocyte morphology in the mare. Theriogenology, 1991, vol. 36, n. 2, p. 157-168. http //dx.doi. org/10.1016/0093-691X(91)90375-N. PMid:16726989.

IACONO, E., MERLO, B., RIZZATO, G. MISLEI, B., GOVONI, N., TAMANINI, C. and MARI, G. Effects of repeated transvaginal ultrasound-guided aspirations performed in anestrous and cyclic mares on $\mathrm{P} 4$ and E2 plasmalevels and luteal function. Theriogenology, 2014, vol. 82, n. 2, p. 225-231 http://dx.doi.org/10.1016/j. theriogenology.2014 03.025. PMid:24780115.

JACOBSON, CC, CHOI, YH, HAYDEN, SS. and HINRICHS, K. Recovery of mare oocytes on a fixed biweekly schedule, and resulting blastocyst formation after intracytoplasmic sperm injection. Theriogenology, 2010, vol. 73, n. 8, p. 1116-1126. http://dx.doi. org/10.1016/j.theriogenology.2010.01.013. PMid:20202674.

LEON-QUINTO T., SIMON, MA., CADENAS, R., JONES, J., MARTINEZ-HERNANDEZ, FJ., MORENO, JM., VARGAS, A. MAR TINEZ, F. and SORIA, B. Developing biological resource banks as a supporting tool for wildlife reproduction and conservation. The Iberian lynx bank as a model for other endangered species. Animal Reproduction Science, 2009, vol. 112, n. 3-4, p. 347-361. http:// dx.doi.org/10.1016/j.anireprosci.2008.05.070. PMid:18585877.

LOOMIS, PR. Techniques and applications of artificial insemination with frozen equine semen. Journal of Equine Veterinary Science, 1986, vol. 6, n. 3, p. 139-142. http://dx.doi.org/10.1016/S07370806(86)80063-6.

LUCAS, X., MARTÍNEZ, EA., ROCA, J., VÁZQUEZ, JM., GIL, MA., PASTOR, LM. and ALABART, JL. Influence of follicle size on the penetrability of immature pig oocytes for homologous in vitro penetration assay. Theriogenology, 2003, vol. 60, n. 4, p. 659-667. http:// dx.doi.org/10.1016/S0093-691X(03)00077-3. PMid:12832015.

LUCCI, CM., AMORIM, CA., RODRIGUES, APR., FIGUEIREDO, JR., BÁO, SN., SILVA, JRV. and GONÇALVES, PB. Study of preantral follicle population in situ and after mechanical isolation from caprine ovaries at different reproductive stages. Animal Reproduction Science, 1999, vol. 56, n. 3-4, p. 223-236. http://dx.doi.org/10.1016/ S0378-4320(99)00045-7. PMid:10497918.

LUCCI, CM., KACINSKIS, MA., LOPES, LHR., RUMPH, R. and BÁO, SN. Effect of different cryoprotectants on the structural preservation of follicles in frozen zebu bovine (Bos indicus) ovarian tissue. Theriogenology, 2004, vol. 61, n. 6, p. 1101-1114. http:// dx.doi.org/10.1016/j.theriogenology.2003.06.004. PMid:15036998. MÜLlER, K., ELLENBERGER, C. and SCHOON, HA. Histomorphological and immunohistochemical study of angiogenesis and angiogenic factors in the ovary of the mare. Research in Veterinary Science, 2009, vol. 87, n. 3, p. 421-431/http:/dx.doi.org/10.1016/j. rvsc.2009.04.011. PMid:1944745

PAVLOK, A., LUCAS-HAHN, A. and NIEMANN, H. Fertilization and developmental competence of bovine oocytes derived from different categories of antral follicles. Molecular Reproduction and Development, 1992, vol 31, n. 1, p. 63-67. http://dx.doi.org/10.1002/ mrd.1080310111. PMid: 1562328 .

PESSOA, MA., CANNIZZA, AP, REGHINI, MAS. and ALVARENGA, MA. Embryo transfer efficiency of Quarter Horse athletic mares. Journal of Equine Veterinary Science, 2011, vol. 31, n. 12, p. 703-705. http://dx.doi.org/ 10.1016/j.jevs.2011.06.001.

REICHENBACH, HD., WIEBKE, NH., MÖDL, J., ZHU, J. and BREM, G. Laparoscopy through the vaginal fornix of cows for the repeated aspiration of follicular oocytes. The Veterinary Record, 1994, yol. 135 n. 15, p. 353-356. PMid:7846823.

SAMPER, JC., MORRIS, L., PEÑA, FJ. and PLOUGH, TA. Commercial breeding with sexed stallion semen: Reality or fiction? Journal of Equine Veterinary Science, 2012, vol. 32, n. 8, p. 471-474. http://dx.doi.org/10.1016/j.jevs.2012.06.018.

SILVA-SANTOS, KC., SANTOS, GMG., SILOTO, LS., HERTEL, MF., ANDRADE, ER., RUBIN, MIB., STURION, L., MELOSTERZA, FA. and SENEDA, MM. Estimate of the population of preantral follicles in the ovaries of Bos taurus indicus and Bos taurus taurus cattle. Theriogenology, 2011, vol. 76, n. 6, p. 1051-1057. http:// dx.doi.org/10.1016/j.theriogenology.2011.05.008. PMid:21722949.

STANSFIELD, FJ., PICTON, HM. and NÖTHLING, JA. Early primary-rather than primordial follicles constitute the main follicular reserve in the African elephant (Loxodonta africana). Animal Reproduction Science, 2011, vol. 123, n. 1-2, p. 112-118. http:// dx.doi.org/10.1016/j.anireprosci.2010.11.003. PMid:21126835.

SUTTON-MCDOWALL, ML., YELLAND, R., MACMILLAN, KL., ROBKER, RL. and THOMPSON, JG. study relating the composition of follicular fluid and blood plasma from individual Holstein dairy cows to the in vitro developmental competence of pooled abattoir-derived oocytes. Theriogenology, 2014, vol. 82, n. 1, p. 95-103. http://dx.doi. org/10.1016/j.theriogenology.2014.03.011. PMid:24746097.

SZLACHTA, M. and TISCHNER, M. Distribution, morphology and ultrastructure of preantral follicles in the ovary of the mare. Havemeyer Foundation Monograph Series / Dorothy Russell Havemeyer Foundation. Dorothy Russell Havemeyer Foundation, 1998, vol. 5, p. 33-35.

TEISSIER, MP., CHABLE, H., PAULHAC, S. and AUBARD, Y. Comparison of follicle steroidogenesis from normal and polycystic in woman undergoing IVF: relationship between steroid concentrations, follicle size, oocyte quality and fecundability. Human Reproduction (Oxford, England), 2000, vol. 15, n. 12, p. 2471-2477. http://dx.doi. org/10.1093/humrep/15.12.2471. PMid:11098013. 
THARASANIT, T., COLLEONI, S., LAZZARI, G., COLENBRANDER, B., GALLI, C. and STOUT, TAE. Effect of cumulus morphology and maturation stage on the cryopreservability of equine oocytes. Reproduction (Cambridge, England), 2006, vol. 132, n. 5, p. 759769. http://dx.doi.org/10.1530/rep.1.01156. PMid:17071777.

WALT, ML., STABENFELDT, GH., HUGHES, JP., NEELY, DP. and BRADBURY, R. Development of equine ovary and ovulation fossa. Journal of Reproduction and Fertility, 1979, vol. 27, n. 27, p. 471-477. PMid:289826.
ZÚCCARI, CESN., BENDER, ESC., SILVA, EVC. and SATURNINO, HM. Eficiência reprodutiva e dinâmica folicular de éguas Campolina de acordo com a condição corporal. Ciência Animal Brasileira, 2013, vol. 14, p. 406-412.
Received February 15, 2015 Accepted November 20,2015

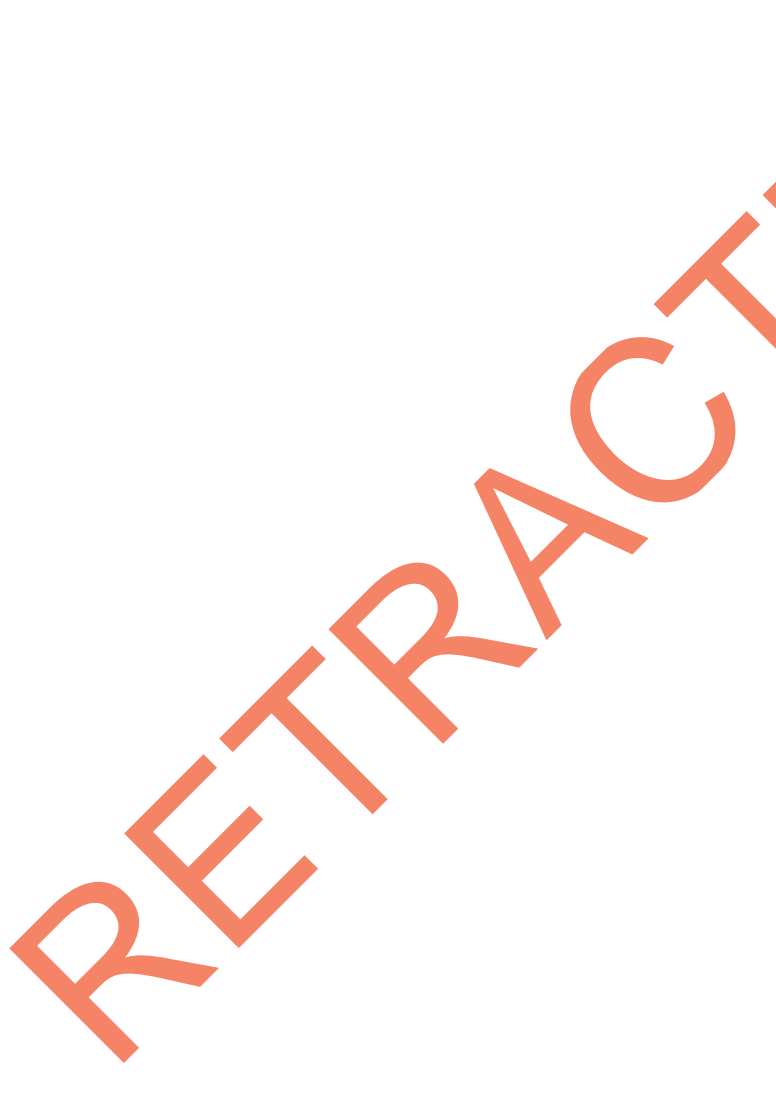

